\title{
Ice disturbance intensity structures benthic communities in nearshore Antarctic waters
}

\author{
Dan A. Smale* \\ British Antarctic Survey, Natural Environment Research Council, High Cross, Madingley Road, Cambridge CB3 0ET, UK
}

\begin{abstract}
Ice scouring is one of the 5 most significant natural forces acting on ecosystems, yet very few data exist linking the intensity of ice disturbance with parameters of benthic community structure. The benthos at 2 nearshore sites on Adelaide Island, Antarctica, was sampled at 3 resolutions to make novel links between biological data and empirical disturbance data from the literature. A total of 125 taxa and $>70000$ individuals were recorded. A total of 8 parameters of community structure were measured; all of them were negatively correlated to disturbance intensity at one site, whilst 6 significant relationships were found at the other site. At 2 of the 3 sampling resolutions, disturbance, rather than depth or the percentage cover of major substratum types, was the environmental variable most correlated with the patterns in community structure. Furthermore, biological samples were divided into 3 categories based on the disturbance data (low, moderate and high). Each group was statistically dissimilar and the relative abundance of sessile fauna decreased as disturbance intensity increased. The intensity of disturbance was broadly correlated with depth, but small-scale differences in topography and substratum type created small-scale refugia, which supported richer assemblages. Overall, both study sites were disturbed frequently and no evidence of a peak in richness at the moderately disturbed locations was recorded.
\end{abstract}

KEY WORDS: Ice scouring $\cdot$ Community structure $\cdot$ Antarctica $\cdot$ Polar benthos

\section{INTRODUCTION}

Ice disturbance is a key structural force acting on shallow water benthic communities at high latitudes (e.g. Dayton et al. 1970, Peck et al. 1999, Brown et al. 2004, Conlan \& Kvitek 2005, Smale et al. in press). However, until recently it has not been possible to directly study the influence of disturbance intensity on community structure, as quantifying ice disturbance is both logistically and experimentally challenging. Instead, proxies for disturbance such as depth (Barnes et al. 1996, Nonato et al. 2000), topographical protection from iceberg scouring (Sahade et al. 1998, Conlan \& Kvitek 2005) and proximity to glaciers (Pugh \& Davenport 1997) have been used to investigate the effect of ice disturbance on polar marine communities.

It has been suggested that where ice disturbance is frequent and severe, benthic communities are held at early successional stages (McCook \& Chapman 1993,
Barnes 1995a, Pugh \& Davenport 1997) dominated by mobile secondary consumers (Richardson \& Hedgepeth 1977, Conlan et al. 1998, Conlan \& Kvitek 2005) and have skewed population structures (Peck \& Bullough 1993, Brown et al. 2004). Furthermore, the intensity of ice disturbance, in the forms of encasement by the ice foot, ice scouring and anchor ice formation, is related (to varying degrees) to depth (Barnes 1995b, Lenihan \& Oliver 1995, Waller et al. 2006, Smale et al. 2007). As a result, many nearshore communities change along a bathymetric gradient at high latitudes, although such transitions can be highly patchy (Dayton et al. 1970, Gambi et al. 1994, 2000, Nonato et al. 2000, Barnes \& Brockington 2003).

To date, only 2 attempts have been made to link empirical ice disturbance data with parameters of nearshore polar benthic community structure; one concerned anchor ice uplift, and the second quantified iceberg scouring. Lenihan \& Oliver (1995) used exper- 
imental stakes to assess the relative force of anchor ice uplift along a depth gradient. The shallow subtidal zone (4 $\mathrm{m}$ depth) was intensely disturbed by anchor ice and, as a result, was dominated by motile opportunistic infauna. Also, total densities of infauna and the number of sedentary taxa were negatively related to the intensity of anchor ice disturbance (Lenihan \& Oliver 1995).

Brown et al. (2004) used concrete markers to quantify the frequency of iceberg impacts in 2 adjacent coves at Adelaide Island, Antarctica. Their study showed, for the first time, that a single point on the seabed at $10 \mathrm{~m}$ depth may be impacted by icebergs more than 3 times in a 2 yr period (Brown et al. 2004). One of their study sites was, on average, disturbed twice as often as the other, and encrusting bryozoan assemblages were less diverse, covered less space and were shorter-lived at the more frequently disturbed site (Brown et al. 2004). Smale et al. (2007) developed the methods used by Brown et al. (2004) and evaluated the intensity of ice disturbance at 24 positions, across 4 depth increments at the same 2 sites over a 2 yr period.
Their study showed that the frequency and intensity of ice disturbance varied significantly with depth, season and site. In the current study, the benthos at each of the positions monitored by Smale et al. (2007) was comprehensively sampled in order to make novel and detailed links between environmental parameters and benthic community structure. Two main hypotheses were tested: (1) measures of assemblage composition (abundance, species richness, biomass and space coverage) all decrease with increasing intensity of ice disturbance, and (2) ice-mediated disturbance is the most important of the environmental variables influencing community structure in the Antarctic shallows.

\section{MATERIALS AND METHODS}

Study site. Sampling was conducted at Hangar Cove and South Cove, 2 sites adjacent to the British Antarctic Survey research station at Rothera Point, Adelaide Island, West Antarctic Peninsula (67³4.5' S, 68 07.0' W) (Fig. 1). The substratum at South Cove is a mixture of

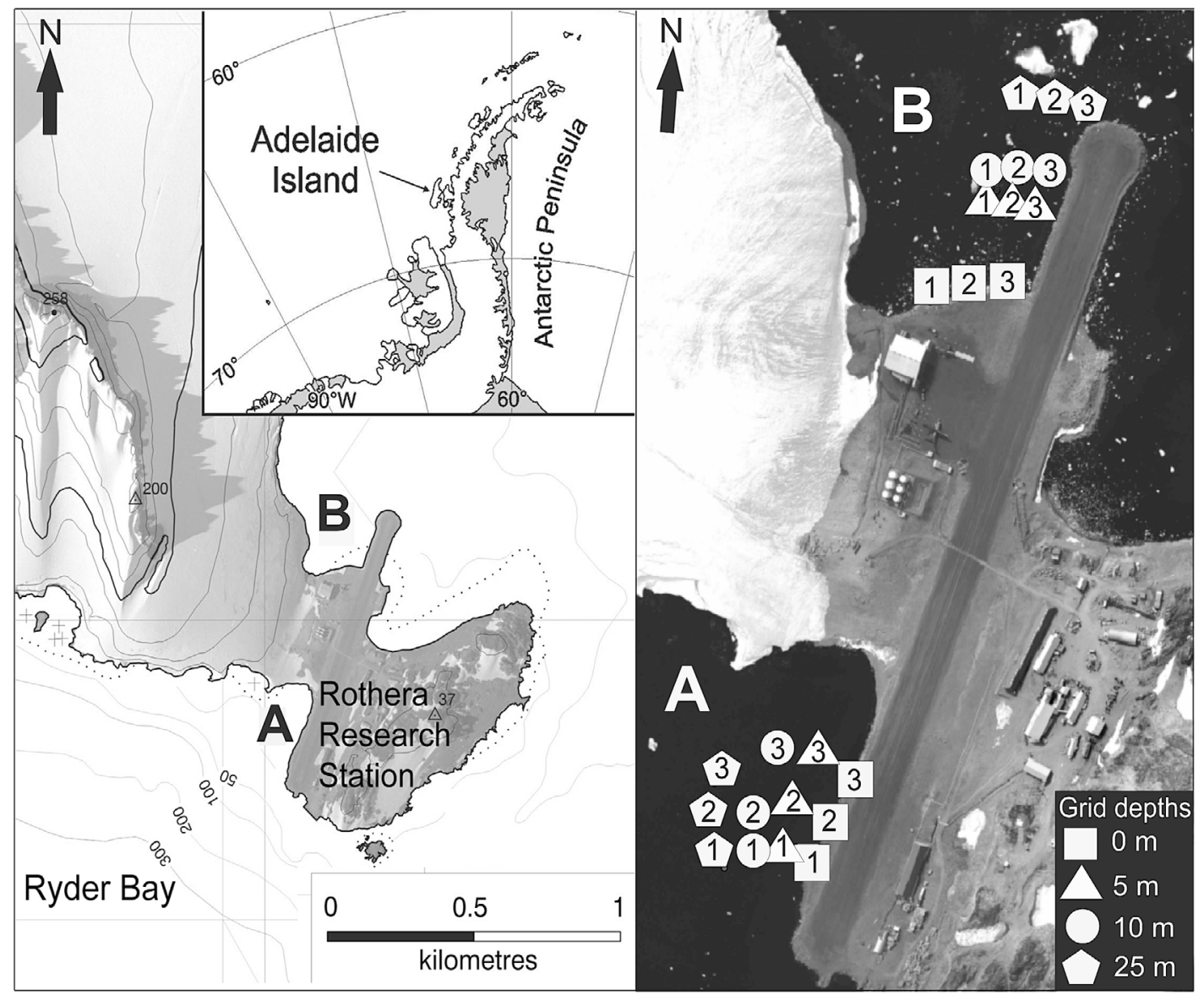

Fig.1. Location of the South Cove (A) and Hangar Cove (B) study sites on Adelaide Island, Antarctica (left). Inset (top) shows position of Adelaide Island on the Antarctic Peninsula. Small-scale aerial photograph (right) indicates positions of disturbance grids at each depth increment, and the orientation of transects (labelled 1 to 3) at each site (adapted from Smale et al. 2007) 
hard bedrock and compacted cobbles with some isolated patches of silt. The site is known to support a high abundance and richness of megafauna, macrofauna and cryptic fauna (Barnes \& Brockington 2003, Bowden 2005, Smale et al. in press). Conversely, Hangar Cove is primarily a soft sediment habitat; a base of compacted cobbles is covered by a layer of silt that varies in thickness from 0 to $\sim 20 \mathrm{~cm}$. Some patches of cobbles are exposed and the site supports an abundant infauna (Smale et al. in press). Both sites have a gently sloping topography, are covered by fast ice during winter (for 4 to $8 \mathrm{mo}$ ) and are disturbed by icebergs, brash (small pieces of glacial ice) and sea ice floes during summer. Brockington and Clarke (2001) give a full description of seawater conditions at this location.

Smale et al. (2007) recently assessed the degree of ice scouring at these sites by deploying a series of grids consisting of concrete and clay markers. Twelve disturbance grids (each grid consisted of 25 markers) were deployed at each site, with triplicate grids laid at $0 \mathrm{~m}$ (extreme low water), $5 \mathrm{~m}, 10 \mathrm{~m}$ and $25 \mathrm{~m}$ depth (Fig. 1). If a marker was impacted by ice, either the clay section (low intensity impact) or the concrete section (high intensity impact) was damaged. Each marker was surveyed and replaced (if necessary) every 3 mo during a 2 yr survey; over 1500 markers were damaged by ice during the study. A measure of the intensity of ice disturbance $\left(I_{d}\right)$, which was based on both the number of times and with what force each marker was hit, was recorded for each grid location. For the current study, grids were grouped into 3 classes based on these data; disturbance group 1 included the least disturbed grids $\left(\mathrm{I}_{\mathrm{d}}=0-100\right)$, group 2 included moderately disturbed grids $\left(I_{d}=101-200\right)$, and disturbance group 3 consisted of the most intensely disturbed grids $\left(I_{d}>201\right)$ (Table 1). Smale et al. (2007) observed a significant relationship between depth and disturbance frequency, and suggested that South Cove was scoured 1.5 times more frequently than Hangar Cove during the $2 \mathrm{yr}$ study period (see Table 1 and Smale et al. 2007 for details). Each disturbance grid covered an area of seabed of $16 \mathrm{~m}^{2}$ and samples for the current study were collected randomly from within each disturbance grid.

Sampling design. Bowden (2005) showed that at these sites (and probably generally), sampling resolu- tion had a significant effect on the type and size of fauna detected and analysed. The benthic communities at each disturbance grid were sampled at 3 levels of resolution. The methods described below were repeated at each of the 24 disturbance grids. Accordingly, a total of 240 photoquadrats, 72 benthic samples and 240 rocks were analysed. Macroalgae were not sampled as they were completely absent from the study areas at Hangar Cove and were diminutive, species poor and patchily distributed at South Cove. All sampling was conducted during the austral summer of 2005 to 2006, after the 2 yr survey of the disturbance grids.

Megafauna: Twenty digital photoquadrats were taken at each grid. From this pool, 10 photoquadrats were randomly selected for analysis. A Nikon D100 digital SLR camera fitted with a Nikkor 12-24 mm DX lens was housed in a Nexus D100 casing and used throughout the sampling. Lighting was achieved by a single Nikonos SB105 flash unit fitted with a diffuser. A carbon fibre framer was fitted to standardise the area sampled and to ensure the camera remained perpendicular to the seabed. Each image was cropped to give 
a sample area of $0.32 \mathrm{~m}^{2}$ and all discernable fauna greater than $5 \mathrm{~mm}$ in size were identified to the lowest possible taxonomic level. All individuals of solitary taxa were counted, whilst modular taxa (sponges, bryozoans and ascidians) were quantified by the number of colonies/units.

Macrofauna: At South Cove, which consists primarily of cobbles and patches of silt, 3 replicate $0.03 \mathrm{~m}^{2}$ randomly placed quadrats were hand cleared by SCUBA divers. The silt layer at Hangar Cove was too thin to effectively core, so a scoop and mesh sampler was used to sample a $0.03 \mathrm{~m}^{2}$ area of sediment to a depth of $2 \mathrm{~cm}$. Again, 3 samples were collected from each disturbance grid. All samples were sieved through a $0.5 \mathrm{~mm}$ mesh, coarsely sorted and preserved in $70 \%$ ethanol. Specimens were sorted to a minimum of family level, although most taxa were identified to species. All taxa were counted for abundance values and wet weights for all fauna were obtained for biomass analysis.

Cryptofauna: Twenty cobbles (i.e. 64 to $256 \mathrm{~mm}$ in diameter, Wentworth 1922) were collected by SCUBA divers from each grid. From this pool of rocks, 10 were selected at random, dried, labelled and later analysed. The total surface area of each rock was estimated using graph paper; the proportion of rock surface left uncovered by sediment and available for colonisation was not clearly defined (perhaps because of frequent turnover). Bryozoans were identified to species level, and abundance (number of colonies) and areal coverage were recorded for each rock. The abundances of other encrusting taxa (principally serpulids and spirorbids, but also sponges) were also recorded.

Environmental variables: The community parameters measured from the 3 sampling protocols described above were related to 3 environmental variables: depth, intensity of disturbance (and the resultant groupings, as measured by Smale et al. 2007), and the percentage surface cover of hard substrata (bedrock and semi-stable substrata), as opposed to soft sediments at each grid. The percentage cover of each substratum type was estimated by projecting a grid onto the 10 photoquadrats collected for the macrofauna survey. Although this was a rather crude estimation, it allowed the inclusion of a broad-scale measure of substratum type in the analysis.

Statistical analysis. Replicate samples from each disturbance grid were pooled to give megafaunal abundance and species richness per unit area $\left(3.2 \mathrm{~m}^{2}\right)$, macrofaunal abundance, species richness and biomass per unit area $\left(0.09 \mathrm{~m}^{2}\right)$, and cryptofaunal abundance, species richness and percentage cover per 10 rocks. The relationships between these univariate biological parameters and the environmental variables were assessed using regression analysis in Minitab 14.0 (significance accepted at $\mathrm{p}<0.05$ for all tests).
Multivariate analyses of community structure were performed using the Primer v. 6 statistical package. Bray-Curtis similarity matrices were produced based on the abundances of megafauna, macrofauna and cryptofauna, which were pre-treated with 4 th root transformations to down-weight the influence of highly abundant taxa. The relatedness of the communities at each grid was assessed using multidimensional scaling (MDS), whilst the strengths of the groupings of depth, disturbance and site factors were tested using the analysis of similarities (2-way ANOSIM) procedure.

The BIOENV routine, which correlates environmental data with differences in community data (following normalisation of environmental data and the construction of a matrix based on Euclidian distance), was applied to determine which physical factor (depth, disturbance or hard substrata cover) best explained the observed patterns in community structure. Subequently, a model matrix generated from similarities in disturbance intensity scores $\left(\mathrm{I}_{\mathrm{d}}\right)$ was correlated with the biological matrices using the RELATE routine. Finally, the species contributing most to the observed differences between disturbance groups and sites were determined using the similarity percentages (2-way SIMPER) analysis.

\section{RESULTS}

A total of 125 taxa was recorded (see Appendix 1); 36, 94 and 16 different taxa were identified from the megafauna, macrofauna and cryptofauna surveys, respectively (21 taxa were recorded at more than one sampling level). Fourteen phyla and 22 classes were represented by these taxa. Approximately 11000 individuals were counted in megafauna samples, 21 000 in macrofauna samples, and 40000 encrusting individuals/colonies were counted on rocks. Initially, cumulative species dominance plots ( $k$-dominance curves) were generated for each disturbance group at each sampling level (Fig. 2). As could be predicted, $k$-dominance curves for disturbance group 3, which included samples from the most intensely disturbed grids, had the greatest $y$-axis intercepts and were more elevated than the plots for the less disturbed samples. This suggested that dominance was greater and diversity lower in these samples compared with those in disturbance groups 1 and 2 (Fig. 2). Conversely, plots for the least disturbed samples (group 1) were higher in diversity and less dominated by a small number of species. These patterns suggested that the disturbance groupings applied to the biological samples on the basis of the disturbance intensity data $\left(\mathrm{I}_{\mathrm{d}}\right)$ were ecologically relevant and therefore a suitable grouping structure for further analysis. 


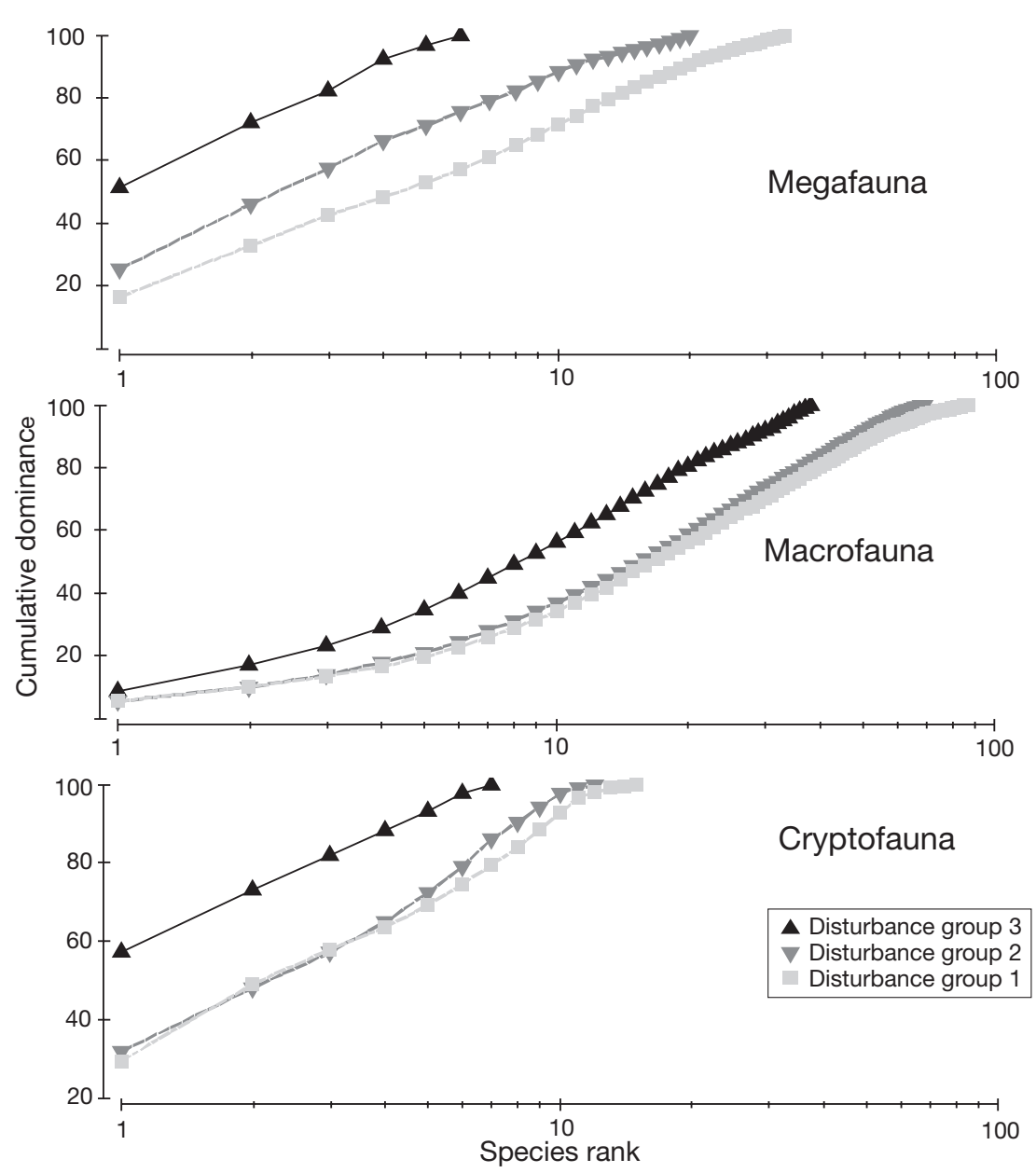

Fig. 2. Cumulative species dominance curves (South Cove and Hangar Cove pooled) at each sampling resolution level for each disturbance group at Adelaide Island, Antarctica. Disturbance group 1 relates to grid locations that were least frequently disturbed, whilst grids in group 3 were most disturbed

parameters were generally weaker compared with South Cove. Even so, megafaunal abundance $\left(\mathrm{R}^{2}=58.8, \mathrm{p}=\right.$ $0.004)$, macrofaunal abundance $\left(\mathrm{R}^{2}=\right.$ $62.4, \mathrm{p}=0.002)$ and richness $\left(\mathrm{R}^{2}=68.9\right.$, $\mathrm{p}<0.001$ ), and cryptofaunal abundance $\left(\mathrm{R}^{2}=55.3, \mathrm{p}=0.006\right)$ all demonstrated strong inverse linearity with disturbance intensity (Fig. 3).

Multivariate analysis of species abundance data indicated that assemblages were significantly different between sites at the megafauna sampling level (2-way ANOSIM with site and depth, global R for site $=0.852, \mathrm{p}=0.001$ ), macrofauna sampling level (global $\mathrm{R}$ for site $=1, p=0.001$ ) and the cryptofauna sampling level (global $\mathrm{R}$ for site = $0.315, p=0.006$ ). MDS ordinations of samples from each grid also suggested some grouping structure based on depth (Fig. 4), and global ANOSIM R values for depth were $>0.5$ and highly significant at all sampling levels. For example, megafauna and macrofauna assemblages at $0 \mathrm{~m}$ depth were low in both the number of species and density of fauna compared with other depths, and this is reflected in the distinct groupings of these samples. Depth and disturbance intensity are broadly correlated (see Smale et al. 2007) and an overlaying bubble plot of disturbance intensity showed that, rather intuitively, samples on the MDS ordinations were also arranged along a disturbance gra-

Regression analysis was used to explain the relationships between disturbance intensity and univariate patterns of community structure at the grid locations. Abundance, species richness, biomass and areal coverage were all significantly inversely related to the intensity of disturbance at South Cove (Fig. 3). At Hangar Cove, there were no significant relationships between disturbance and macrofaunal biomass and cryptofaunal species richness, whilst the other 6 biological parameters were negatively correlated with disturbance (Fig. 3). The strongest correlations were found at South Cove; species richness data at all sampling levels decreased significantly with increasing disturbance intensity (all $\mathrm{R}^{2}$ values $>79.0$, all $\mathrm{p}<0.001$ ), whilst macrofaunal abundance $\left(\mathrm{R}^{2}=68.4, \mathrm{p}<0.001\right)$ and biomass $\left(\mathrm{R}^{2}=83.5, \mathrm{p}<0.001\right)$, and cryptofaunal areal coverage $\left(R^{2}=63.9, p=0.002\right)$ all decreased exponentially with increasing disturbance. At Hangar Cove, correlations between disturbance intensity and community dient. This was particularly evident for cryptofauna (Fig. 4). The significance of any grouping structure based on disturbance was then tested with a 2-way ANOSIM, with site and disturbance groupings as factors. Overall, the 3 disturbance groups were statistically distinct, although the degree of dissimilarity between groups was moderate (Table 2).

The BIOENV procedure indicated that disturbance intensity was the environmental variable that best grouped the disturbance grids in a manner consistent with the biological data. The megafauna samples from South Cove were best correlated with depth and disturbance, whilst all other sample sets from both sites were best correlated with disturbance as a single variable (Table 2). Subsequently, a model matrix generated from the disturbance scores was correlated with the biological similarity matrices using the RELATE test. All sampling levels were significantly correlated with the model matrix, indicating a continuum of com- 

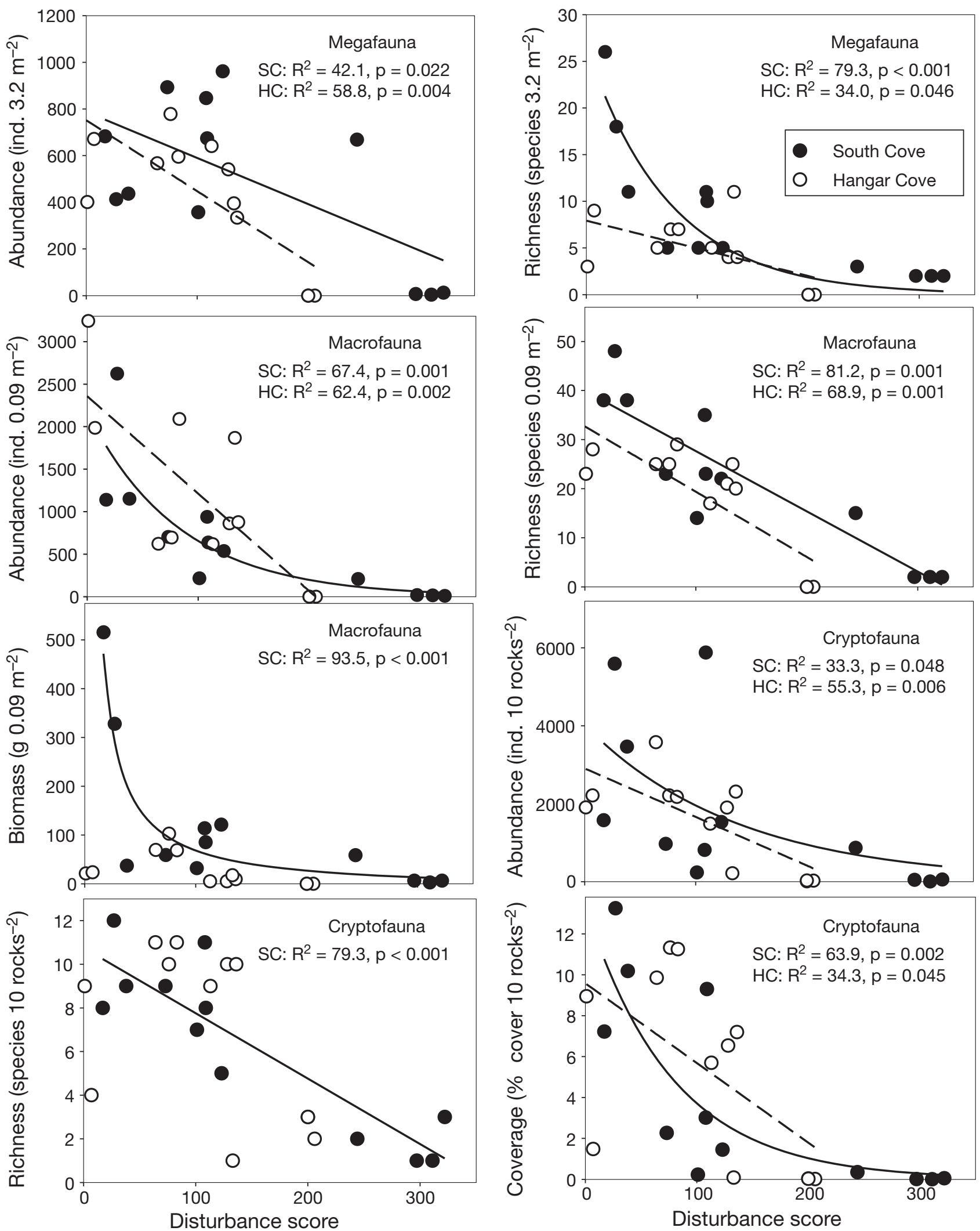

Fig. 3. Plots of biological parameters against disturbance score $\left(\mathrm{I}_{\mathrm{d}}\right)$ for each disturbance grid deployed at South Cove (SC) and Hangar Cove (HC), Adelaide Island, Antarctica. The significant regressions through data from each site are shown $($ South Cove $=$ solid lines, Hangar Cove = broken lines) 
munity change from low disturbance to high disturbance grids (Table 2). The strength of the correlations between each sampling level and the model matrix ranged from moderate (South Cove cryptofauna, $\rho=0.416, p=0.007$ ) to high (Hangar Cove macrofauna, $\rho=$ $0.785, \mathrm{p}=0.001$ ). Interestingly, the correlations were generally greater at Hangar Cove than South Cove, and the weakest correlations were found for the cryptofauna samples at both sites.

SIMPER analysis determined which individual taxa contributed most to the observed dissimilarity between the disturbance groups (Table 3). Notably, the overall dissimilarity between assemblages sampled at the moderate and highly disturbed grids was consistently much greater than the dissimilarity between the low and moderately disturbed grids. At all sampling levels the number of species and individuals sampled at the high disturbance grids (group 3) was considerably lower than at the low and moderate disturbance grids (groups 1 and 2). Hence, even after a 4th root transformation to down-weight abundant species, the taxa responsible for the dissimilarities between groups 2 and 3 were simply the most abundant taxa in the group 2 samples. At the megafauna sampling level, the highly abundant and motile limpet Nacella concinna and sea urchin Sterechinus neumayeri were major contributors to the dissimilarity between groups 2 and 3, whilst the differences in macrofauna were due largely to the bivalve Mysella charcoti and the polychaete Leitoscoloplos kerguelensis (both of which had greater abundances in the moderately disturbed samples compared with highly disturbed samples, see Table 3).

Fig. 4. Left: MDS ordinations of abundance data collected from disturbance grids at each site (symbols) and depth (numerals). Bray-Curtis similarities were calculated from 4th-root transformed data. Right: Duplicate MDS ordinations with overlaying bubble plots to represent disturbance intensity scores (plot areas $=\mathrm{I}_{\mathrm{d}}$ ) for each grid.

Labels indicate the depth of each grid
Table 2. Results of multivariate tests applied to 4th-root transformed abundance data collected at each disturbance grid location. Two-way ANOSIM tests (site and disturbance) were used to assess the overall dissimilarity between disturbance groups (999 random permutations). The environmental variable(s) that best described the biological patterns were determined by using the BIOENV routine with continuous disturbance, depth and \% cover of substratum data. The model matrix used for the RELATE test was generated from similarities in disturbance values $\left(I_{d}\right)$ between samples. This matrix was then correlated with the biological similarity matrix for each sampling level. dist. $=$ disturbance, Corr. $=$ Correlation

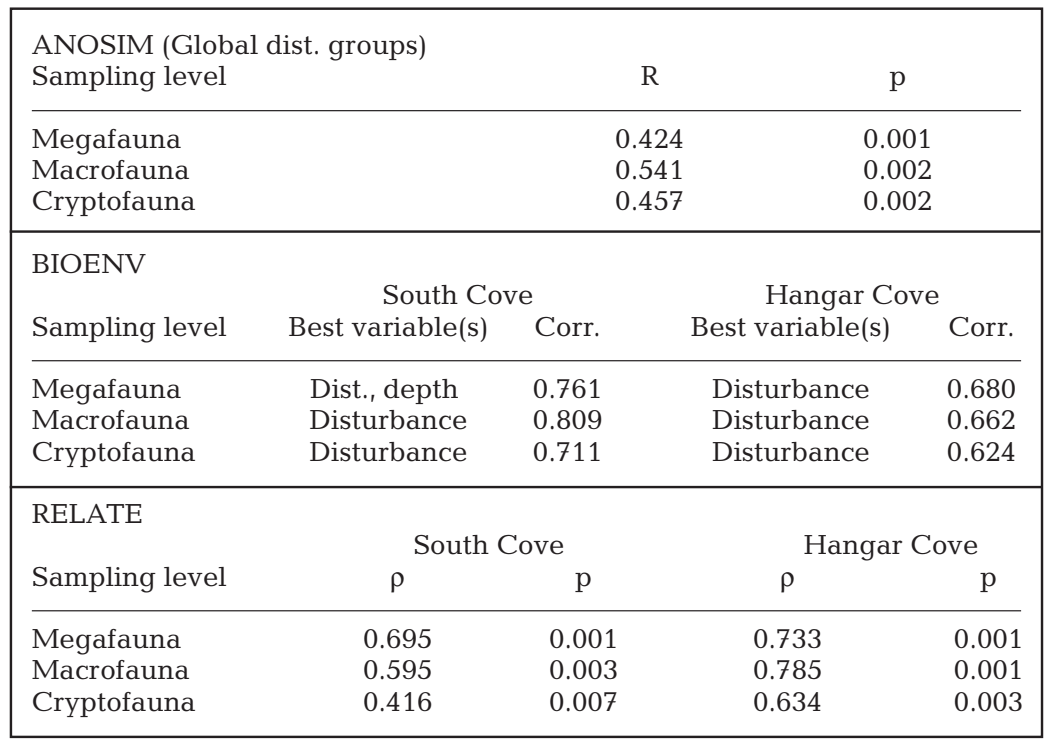

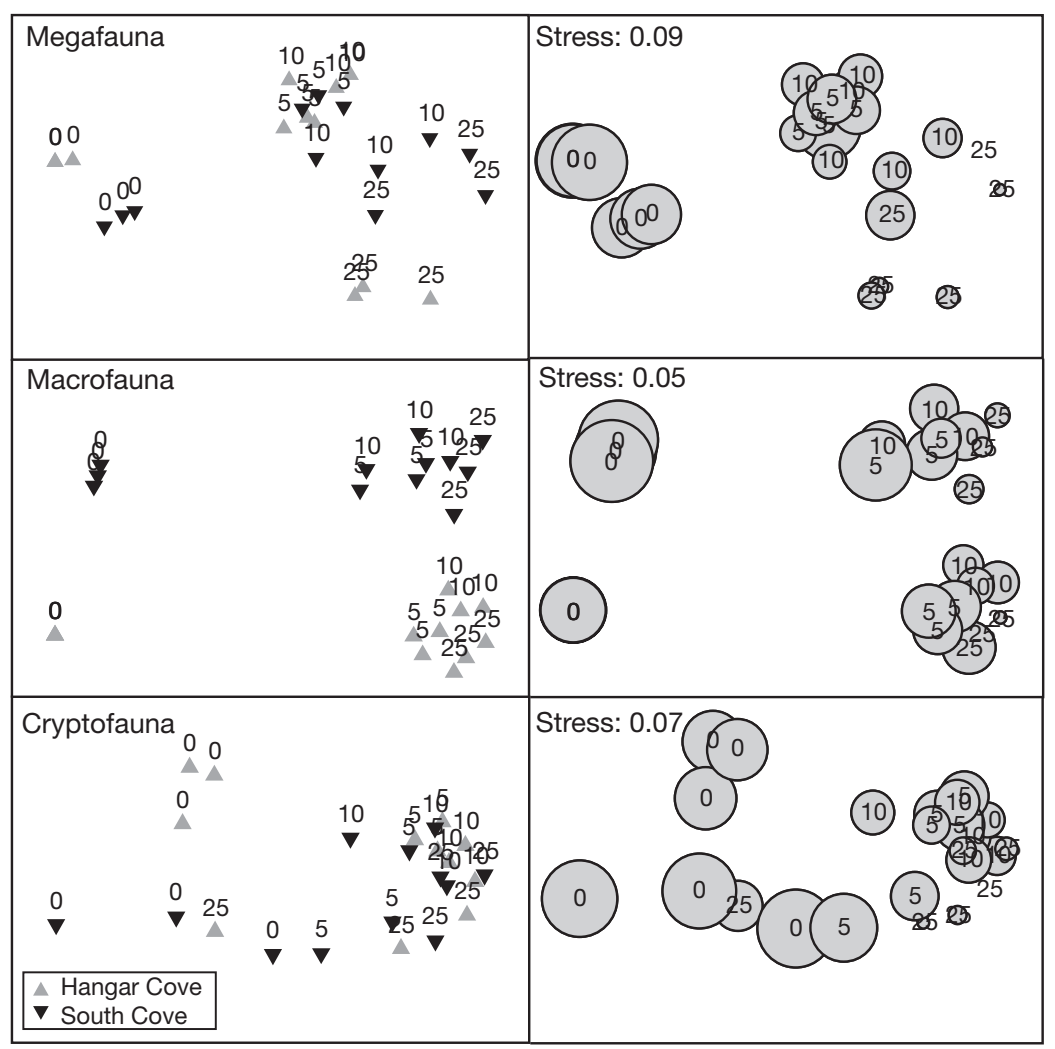


Table 3. The 5 taxa (at each sampling resolution level) contributing most to the observed differences between disturbance groupings (Dist. groups), as determined by the SIMPER routine (2-way with site and disturbance on 4 th-root transformed data). Dist. group 1 relates to the least disturbed grids, Dist. group 3 the most intensely disturbed. Overall dissimilarity between groups shown in parentheses. Average abundances for each disturbance group (Av. Ab.) and percentage of dissimilarity, individually (Ind.\%) and cumulatively (Cum.\%), explained by each taxon are shown. Indet. = unidentified

\begin{tabular}{|c|c|c|c|c|c|}
\hline Dist. groups & Taxa & Av.Ab.1 & Av. Ab.2 & Ind. $\%$ & Cum. \% \\
\hline \multicolumn{6}{|l|}{ Megafauna } \\
\hline 1 and 2 & Nacella concinna & 3.14 & 3.90 & 13.77 & 13.77 \\
\hline \multirow[t]{4}{*}{$(45.47 \%)$} & Ophionotus victoriae & 1.93 & 1.74 & 12.04 & 25.81 \\
\hline & Laternula elliptica & 0.91 & 0.49 & 9.10 & 34.92 \\
\hline & Parbolasia corrugatus & 0.00 & 0.48 & 5.13 & 40.04 \\
\hline & Sterechinus neumayeri & 3.19 & 3.21 & 4.80 & 44.84 \\
\hline \multirow{5}{*}{$\begin{array}{l}2 \text { and } 3 \\
(71.52 \%)\end{array}$} & Sterechinus neumayeri & 3.21 & 0.88 & 23.03 & 23.03 \\
\hline & Nacella concinna & 3.90 & 2.21 & 21.66 & 44.69 \\
\hline & Ophionotus victoriae & 1.74 & 0.00 & 12.32 & 57.01 \\
\hline & Odontaster validus & 1.39 & 0.43 & 9.22 & 66.23 \\
\hline & Parbolasia corrugatus & 0.48 & 0.00 & 4.85 & 71.08 \\
\hline \multicolumn{6}{|l|}{ Macrofauna } \\
\hline \multirow{5}{*}{$\begin{array}{l}1 \text { and } 2 \\
(39.02 \%)\end{array}$} & Aphelochaetasp. & 2.10 & 1.14 & 3.67 & 3.67 \\
\hline & Nematoda & 2.95 & 1.78 & 3.34 & 7.01 \\
\hline & Mysella charcoti & 3.77 & 2.73 & 3.31 & 10.32 \\
\hline & Ophryotrocha sp. & 1.08 & 1.68 & 2.84 & 13.15 \\
\hline & Leitoscoloplos kerguelensis & $s \quad 2.29$ & 2.30 & 2.62 & 15.77 \\
\hline \multirow{5}{*}{$\begin{array}{l}2 \text { and } 3 \\
(80.62 \%)\end{array}$} & Mysella charcoti & 2.73 & 0.65 & 5.65 & 5.65 \\
\hline & Leitoscoloplos kerguelensis & $s \quad 2.30$ & 0.39 & 4.78 & 10.42 \\
\hline & Eatoniella calignosa & 2.09 & 0.76 & 4.03 & 14.46 \\
\hline & Onoba turqueti & 1.86 & 0.26 & 3.78 & 18.24 \\
\hline & Ophelina breviata & 1.78 & 0.00 & 3.59 & 21.83 \\
\hline \multicolumn{6}{|l|}{ Cryptofauna } \\
\hline 1 and 2 & Fenestrulina rugula & 4.37 & 2.92 & 14.48 & 14.48 \\
\hline \multirow[t]{4}{*}{$(35.81 \%)$} & Spirorbid polychaetes & 6.60 & 5.76 & 12.48 & 26.96 \\
\hline & Smittina rogickae & 1.95 & 0.61 & 11.44 & 38.40 \\
\hline & Indet. Cyclostome sp. a. & 1.19 & 1.65 & 8.32 & 46.72 \\
\hline & Micropora notialis & 1.19 & 0.79 & 7.63 & 54.34 \\
\hline \multirow{5}{*}{$\begin{array}{l}2 \text { and } 3 \\
(62.13 \%)\end{array}$} & Spirorbid polychaetes & 5.76 & 2.94 & 25.17 & 25.17 \\
\hline & Fenestrulina rugula & 2.92 & 0.83 & 15.44 & 40.62 \\
\hline & Hippadanella inerma & 1.45 & 0.45 & 9.60 & 50.22 \\
\hline & Indet. Cyclostome sp. a. & 1.65 & 0.25 & 9.33 & 59.55 \\
\hline & Ellisina antarctica & 1.31 & 0.00 & 9.29 & 68.84 \\
\hline
\end{tabular}

The data also suggested a shift in life strategies with changing disturbance intensity, as the relative abundance of sessile fauna generally increased with decreasing disturbance (Fig. 5). Variation within each group was high, and differences between each group were non-significant. However, an overall linear regression of data from both sites showed a significant negative relationship between the disturbance intensity and the relative abundance of sessile fauna. This relationship was stronger at the macrofauna sampling level $\left(\mathrm{R}^{2}=\right.$ 0.49, $F=21.08, \mathrm{p}=0.000)$ compared with the megafauna level $\left(\mathrm{R}^{2}=0.21, F=5.52\right.$, $\mathrm{p}=0.028)$.

\section{DISCUSSION}

\section{Disturbance intensity}

Disturbance intensity was negatively correlated with almost all of the univariate measures of community structure and was the environmental variable most correlated with the multivariate abundance matrices. Ice disturbance, or more specifically scouring by icebergs and sea ice, is therefore a dominant environmental force acting on shallow water assemblages at Adelaide Island, and probably at similar polar coastal locations. Collisions between ice and benthos in shallow waters have been described as catastrophic (Conlan et al. 1998, Peck et al. 1999, Smale et al. in

Interestingly, Leitoscoloplos kerguelensis, Ophryotrocha sp. and Parborlasia corrugatus are 3 species known to be associated with disturbed sediments (Barnes \& Conlan 2007 and references therein) and had greater abundances at moderately disturbed grids compared with low disturbance grids (Table 3). Other key taxa responsible for the dissimilarities between groups 1 and 2 were the polychaete Aphelochaeta sp., the bivalve mollusc Laternula elliptica, the ophiuroid Ophionotus victoriae and unidentified nematodes, all of which had greater abundances in the low disturbance samples. Spirorbid polychaetes and the cheilostome bryozoan Fenestrulina rugula dominated encrusting assemblages at all grids and their numbers generally increased with decreasing disturbance frequency. As a result, these taxa were the principal contributors to the dissimilarities between all disturbance groups. press) and, even if one considers the deeper waters of the continental shelf, iceberg scouring may be one of the 5 most significant natural disturbances acting on any ecosystem (Gutt \& Starmans 2001). The disturbance data collected by Smale et al. (2007) and linked with biological data in this study were measures of the frequency and force of iceberg impacts at each grid location. Unsurprisingly, within the range of disturbance intensities investigated in the current study, greater disturbance intensity was correlated with lower species richness, evenness, biomass, and space coverage. Communities were broadly distributed along a disturbance gradient and sessile fauna increased in relative abundance as disturbance intensity decreased.

What is counter-intuitive, however, is the significant decrease in total abundance with increasing distur- 


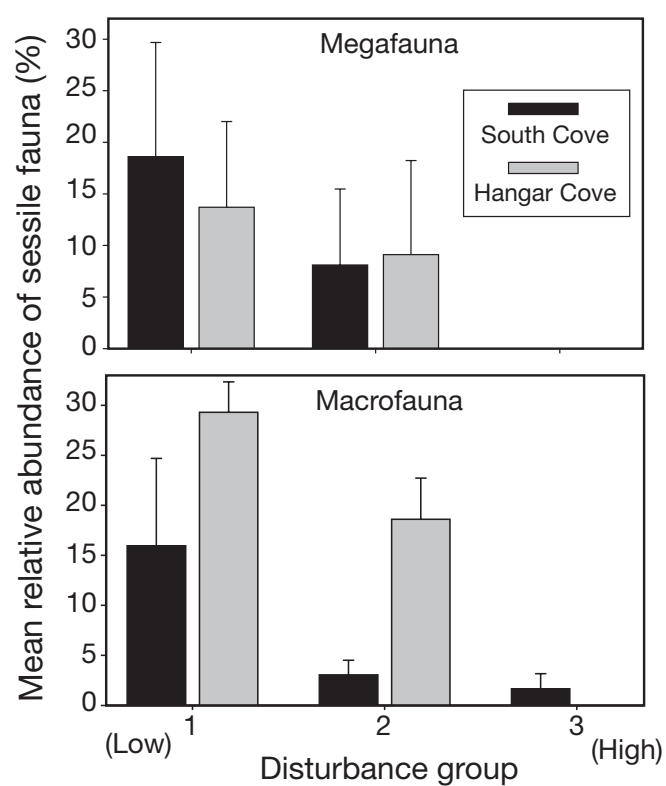

Fig. 5. Relative abundances of sessile fauna for each disturbance group and site. Data are means (+SE) of every grid within each disturbance group for each sampling resolution level

bance recorded at all 3 sampling levels. Classically, highly disturbed areas are characterised by a low diversity of highly abundant pioneers (Pearson \& Rosenberg 1978, Huston 1979, Sousa 1979). A continuous decrease in total abundance was recorded with increasing disturbance, although the strength of this relationship was moderate within the megafauna and cryptofauna sample sets. There are 2 possible explanations for this observation. Firstly, disturbance intensity was so great at the most disturbed grids (disturbance was recorded at some grids on almost every tri-monthly surveying occasion) that pioneer species were either absent or too small to be detected by the sampling method. Therefore, pioneers were abundant at the 'moderately' disturbed grids (there were a number of anomalies in abundance recorded at intermediate levels of disturbance) and perhaps abundance does decrease over a larger-scale disturbance gradient outside the range of this study. For example, typical pioneer species associated with disturbed habitats, such as the polychaetes Leitoscoloplos kerguelensis and Ophryotrocha sp. (both of which were entirely absent from the high disturbance areas) and spirorbid polychaetes, had greater abundances at the moderately disturbed grid locations than at the high disturbance areas and were major contributors to the differences between the 2 disturbance groupings. However, it is important to note that in addition to ice scouring frequency, the carbon content of the sediment, which was not measured in the current study, may also influence the distribution of these deposit feeders (Conlan et al. 2004).
Secondly, the density of large sessile organisms increased as disturbance intensity decreased. At the low-intensity disturbance grids, the presence of large sponges, ascidians, erect bryozoans, terebellid polychaetes and large holothurians created a 3-dimensional microhabitat ('multi-storied assemblages') with space for not only more species, but also more individuals. For example, dense aggregations of the gastropod Eatoniella calignosa, the echinoid Sterechinus neumayeri and the holothurian Cucumaria sp. were observed in areas of low disturbance where sponges and ascidians were present. Large, structural species are an important component of Antarctic benthos (Gray 2001, Teixido et al. 2004) and are known to support a rich and abundant epifauna (Gutt \& Schickan 1998, Gutt \& Starmans 1998, Broyer et al. 2001). At the least disturbed locations in the current study, sessile assemblages had sufficient time between disturbance events to develop (but disturbance was probably frequent enough to prevent mono-specific monopolisation) and created a more complex and spacious living space for an abundant epifauna.

The MDS ordinations of samples at all sampling resolutions suggested that communities at both sites were heterogeneous and patchy. Even at grids with low disturbance values, assemblages were dissimilar and not grouped closely together. Iceberg scouring is an inherently stochastic process and, like other disturbance pressures, promotes patchiness (Sousa 1984, Hall et al. 1992). Over larger spatial scales, patchy mosaics of disturbance events at different stages of recovery may actually increase habitat heterogeneity and niche separation, and therefore promote biodiversity (Gutt 2000, Gutt \& Piepenburg 2003).

Also, the megafauna and macrofauna communities at $0 \mathrm{~m}$ depth (i.e. extreme low water spring tide level) were very poor in both richness and abundance and, as a result, dissimilar to assemblages at other depths. This can be largely explained by the intense scouring by sea ice floes and brash at $0 \mathrm{~m}$ depth; on a number of occasions each of the 150 markers laid on the rocky shore was impacted by ice within $24 \mathrm{~h}$. However, in addition to frequent and intense ice scouring, wave action continually turned over rocks during summer and the entire zone was covered by the ice foot during winter. In contrast, even in stormy conditions, wave disturbance at $>2 \mathrm{~m}$ depth is minimal at South Cove and Hangar Cove (pers. obs.), as they are largely sheltered from oceanic swells. Communities at $0 \mathrm{~m}$ depth were distinct from those at greater depths because of frequent turnover of semistable substrata (Sousa 1979), encapsulation by the ice foot (Barnes 1995a) and chronic ice scouring (Pugh \& Davenport 1997), which resulted in the near denudation of surface life on the rocky shores of Adelaide Island (but see Waller et al. 2006). 


\section{Other environmental variables}

Benthic assemblages were significantly different between the 2 study sites, which differed in a number of characteristics, including exposure to disturbance and substratum type. The substratum at Hangar Cove was predominantly soft sediment, whilst South Cove was characterised by semi-stable hard substrata. It is likely that variation in community structure between locations was a result of differences in a number of localised conditions (see Ragua-Gil et al. 2004), particularly exposure to disturbance and substratum type. Substratum type is a well-known factor influencing the distributions of benthic species at Antarctic locations (Gruzov et al. 1967, Kirkwood \& Burton 1988, Barnes 1995b) and the distribution of major substratum types had a broad scale influence on the assemblages sampled at Adelaide Island.

The intensity of ice scouring in polar regions is broadly correlated with depth (Gutt \& Starmans 2001, Laudien et al. 2007, Smale et al. 2007), but small-scale deviations from the relationship may have an important role in the distribution of species in nearshore waters. Two of the disturbance grids deviated considerably from the depth-disturbance relationship: one of the $5 \mathrm{~m}$ depth grids at South Cove had a relatively low disturbance score and one of the $25 \mathrm{~m}$ depth grids at Hangar Cove had a comparatively high disturbance score. Small-scale differences in topography and substratum type were the most likely cause of these anomalies, although ice scouring frequency is highly variable over time (Smale et al. 2007). The benthic assemblages at these grid locations were similar to those at grids with similar disturbance scores, rather than those at the same depths. To expand, the grid at South Cove at $5 \mathrm{~m}$ depth, protected by a small rise in topography and larger boulders, received fewer impacts than other grids at this depth and the assemblage here was more abundant, speciose and dominated by sessile forms (similar to assemblages at $10 \mathrm{~m}$ depth). Therefore, small-scale spatial variation in disturbance intensity (just 10s of metres) may allow relatively rich communities to develop in close proximity to frequently disturbed assemblages. It seems likely that the development of rich assemblages, acting as sources of potential recruits, may influence the recolonisation of fresh iceberg scours in nearby intensely disturbed areas (Peck et al. 1999, Conlan \& Kvitek 2005).

\section{Ecological models and future change}

In the Arctic, studies on the effects of iceberg scouring in nearshore waters have described peaks in species richness where disturbance intensity is intermedi- ate (Conlan \& Kvitek 2005, Laudien et al. 2007), as could be predicted by the 'intermediate disturbance hypothesis' (Connell 1978, Huston 1979). In the current study, no intermediate peak in richness was recorded within the range of disturbance intensities examined. Icebergs or sea ice impacted almost all of the disturbance grids at least once during the 2 yr survey by Smale et al. (2007), suggesting that these sites are intensely disturbed, even at $25 \mathrm{~m}$ depth. Therefore, it is likely that the assemblages at these sites represent the 'disturbed end' of the disturbance gradient, and species richness may peak at intermediately disturbed locations outside the scope of this study (i.e. in deeper water or more protected sites).

It is currently unclear how climatic change will affect the intensity of ice disturbance acting on Antarctic benthic communities. It has been suggested that glacial retreat and increased iceberg loading into coastal waters will intensify disturbance pressure (Brown et al. 2004), but on the other hand, warmer waters will reduce the life expectancy, and perhaps the population size, of travelling icebergs (see Wadhams 2000 for iceberg decay rates). There are, of course, many other uncertainties involved in predicting future disturbance rates. In the Weddell Sea system, a decreased frequency of disturbance events may be more detrimental to biodiversity than an increase (Johst et al. 2006). However, the data presented here suggest that any increase in the intensity of iceberg scouring would result in assemblages with fewer species, fewer individuals and lower biomass inhabiting the immediate subtidal zone at high latitudes.

Acknowledgements. The author thanks the marine teams of 2005 and 2006, and in particular, dive officers J. Withers and M. Brown, for impeccable field support in often-difficult conditions. I also thank K. Linse, T. Munilla, C. De Broyer, S. Hull, S. Kaiser and B. Hilbig for their taxonomic expertise and D. Barnes and an anonymous referee for constructive criticism of an earlier version of the manuscript. The UK NFSD is acknowledged for providing support to BAS diving operations.

\section{LITERATURE CITED}

Barnes DKA (1995a) Sublittoral epifaunal communities at Signy Island, Antarctica. I. The ice-foot zone. Mar Biol 121:555-563

Barnes DKA (1995b) Sublittoral epifaunal communities at Signy Island, Antarctica. II. Below the ice-foot zone. Mar Biol 121:565-572

Barnes DKA, Brockington S (2003) Zoobenthic biodiversity, biomass and abundance at Adelaide Island, Antarctica. Mar Ecol Prog Ser 249:145-155

Barnes DKA, Conlan KE (2007) Disturbance, colonization and development of Antarctic benthic communities. Phil Trans R Soc Lond B 362:11-38

Barnes DKA, Rothery P, Clarke A (1996) Colonisation and development in encrusting communities from the Antarctic intertidal and sublittoral. J Exp Mar Biol Ecol 196: 251-265 
Bowden DA (2005) Quantitative characterization of shallow marine benthic assemblages at Ryder Bay, Adelaide Island, Antarctica. Mar Biol 146:1235-1249

Brockington S, Clarke A (2001) The relative influence of temperature and food on the metabolism of a marine invertebrate. J Exp Mar Biol Ecol 258:87-99

Brown KM, Fraser KPP, Barnes DKA, Peck LS (2004) Links between the structure of an Antarctic shallow-water community and ice-scour frequency. Oecologia 141:121-129

Broyer CD, Scailteur Y, Chapelle G, Rauschert M (2001) Diversity of epibenthic habitats of gammaridean amphipods in the eastern Weddell Sea. Polar Biol 24:744-753

Conlan KE, Kvitek RG (2005) Recolonization of soft-sediment ice scours on an exposed Arctic coast. Mar Ecol Prog Ser 286:21-42

Conlan KE, Lenihan HS, Kvitek RG, Oliver JS (1998) Ice scour disturbance to benthic communities in the Canadian High Arctic. Mar Ecol Prog Ser 166:1-16

Conlan KE, Kim SL, Lenihan HS, Oliver JS (2004) Benthic changes during 10 years of organic enrichment by McMurdo Station, Antarctica. Mar Poll Bull 49:43-60

Connell JH (1978) Diversity in tropical rainforests and coral reefs. Science 199:1302-1310

Dayton PK, Robbiliard GA, Payne T (1970) Benthic faunal zonation as a result of anchor ice at McMurdo Sound, Antarctica. In: Holdgate MW (ed) Antarctic ecology, Vol 1. Academic Press, New York, p 244-258

Gambi MC, Buia MC, Mazzella L, Lorenti M, Scipioni MB (2000) Spatio-temporal variability in the structure of benthic populations in a physically controlled system off Terra Nova Bay: the shallow hard bottoms. In: Faranda FM, Guglielmo L, Ionora A (eds) Ross Sea ecology. Springer-Verlag, Berlin, p 503-514

Gambi MC, Lorenti M, Russo GF, Scipione MB (1994) Benthic associations of the shallow hard bottoms off Terra Nova Bay, Ross Sea: zonation, biomass and population structure. Antarct Sci 6:449-462

Gray JS (2001) Antarctic marine benthic biodiversity in a world-wide latitudinal context. Polar Biol 24:633-641

Gruzov YN, Propp MV, Pushkin AF (1967) Biological associations of coastal areas of the Davis Sea (based on the observations of divers). Inf Byull Sov Antarkt Eksped 6:523-533

Gutt J (2000) Some "driving forces" structuring communities of the sublittoral Antarctic macrobenthos. Antarct Sci 12:297-313

Gutt J, Piepenburg D (2003) Scale-dependent impact on diversity of Antarctic benthos caused by grounding of icebergs. Mar Ecol Prog Ser 253:77-83

Gutt J, Schickan T (1998) Epibiotic relationships in Antarctic benthos. Antarct Sci 10:398-405

Gutt J, Starmans A (1998) Structure and biodiversity of megabenthos in the Weddell and Lazarev Seas (Antarctica): ecological role of physical parameters and biological interactions. Polar Biol 20:229-247

Gutt J, Starmans A (2001) Quantification of iceberg impact and benthic recolonisation patterns in the Weddell Sea (Antarctica). Polar Biol 24:615-619

Hall SJ, Raffaelli D, Thrush SF (1992) Patchiness and disturbance in shallow water benthic assemblages. In: Giller PS, Hildrew AG, Raffaelli DG (eds) Aquatic ecology: scale, pattern and process. Blackwell Scientific, Oxford, p 333-375

Huston MA (1979) A general hypothesis of species diversity. Am Nat 113:81-101

Johst K, Gutt J, Wissel C, Grimm V (2006) Diversity and disturbances in the Antarctic megabenthos: feasible versus theoretical disturbance ranges. Ecosystems 9:1145-1155
Kirkwood JM, Burton HR (1988) Macrobenthic species assemblages in Ellis Fjord, Vestfold Hills, Antarctica. Mar Biol 97:445-457

Laudien J, Herrmann M, Arntz WE (2007) Soft bottom species richness and diversity as a function of depth and iceberg scour in Arctic glacial Kongsfjorden (Svalbard). Polar Biol 30:1035-1046

Lenihan HS, Oliver JS (1995) Anthropogenic and natural disturbances to marine benthic communities in Antarctica. Ecol Appl 5:311-326

McCook LJ, Chapman ARO (1993) Community succession following massive ice-scour on a rocky intertidal shore: recruitment, competition and predation during early, primary succession. Mar Biol 115:565-575

Nonato EF, Brito TAS, De Paiva PC, Petti MAV, Corbisier TN (2000) Benthic megafauna of the nearshore zone of Martel Inlet (King George Island, South Shetland Islands, Antarctica): depth zonation and underwater observations. Polar Biol 23:580-588

Pearson TH, Rosenberg R (1978) Macrobenthic succession in relation to organic enrichment and pollution of the marine environment. Oceanogr Mar Biol Annu Rev 13:229-311

Peck LS, Brockington S, Vanhove S, Beghyn M (1999) Community recovery following catastrophic iceberg impacts in a soft-sediment shallow-water site at Signy Island, Antarctica. Mar Ecol Prog Ser 186:1-8

Peck LS, Bullough LW (1993) Growth and population structure in the infaunal bivalve Yoldia eightsi in relation to iceberg activity at Signy Island, Antarctica. Mar Biol 117: 235-241

Pugh PJA, Davenport J (1997) Colonisation vs. disturbance: the effects of sustained ice-scouring on intertidal communities. J Exp Mar Biol Ecol 210:1-21

Ragua-Gil JM, Gutt J, Clarke A, Arntz WE (2004) Antarctic shallow-water mega-epibenthos: shaped by circumpolar dispersion or local conditions? Mar Biol 144:829-839

Richardson ME, Hedgepeth JW (1977) Antarctic soft-bottom, macrobenthic community adaptations to a cold, stable, highly productive, glacially affected environment. In: Llano GA (ed) Adaptations within Antarctic ecosystems. Smithsonian Institution Press, Washington, DC, p 181-196

Sahade R, Tatian M, Kowalke J, Kuhne S, Esnal GB (1998) Benthic faunal associations on soft substrates at Potter Cove, King George Island, Antarctica. Polar Biol 19:85-91

Smale DA, Barnes DKA, Fraser KPP (2007) The influence of depth, site exposure and season on the intensity of iceberg scouring in nearshore Antarctic waters. Polar Biol 30:769-779

Smale DA, Barnes DKA, Fraser KPP (in press) The influence of ice scour on benthic communities at three contrasting sites at Adelaide Island, Antarctica. Austral Ecol

Sousa WP (1979) Disturbance in marine intertidal boulder fields: the nonequilibrium maintenance of species diversity. Ecology 60:1225-1239

Sousa WP (1984) The role of disturbance in natural communities. Annu Rev Ecol Syst 15:353-391

Teixido N, Garrabou J, Gutt J, Arntz WE (2004) Recovery in Antarctic benthos after iceberg disturbance: trends in benthic composition, abundance and growth forms. Mar Ecol Prog Ser 278:1-16

Wadhams P (2000) Ice in the ocean. Gordon \& Breach, Amsterdam

Waller C, Barnes DKA, Convey P (2006) Ecological constraints across an Antarctic land-sea interface. Austral Ecol 31:656-666

Wentworth CK (1922) A scale of grade and class terms for clastic sediments. J Geol 30:377-392 
Appendix 1. Full list of taxa sampled at South Cove and Hangar Cove, Adelaide Island, Antarctica, including sampling resolution level(s) (1 = megafauna, 2 = macrofauna and 3 = encrusting fauna) and disturbance group(s) (Dist. group) $(1=$ low disturbance, 3 = high disturbance) in which taxa were recorded. Indet. = unidentified

\begin{tabular}{|c|c|c|c|}
\hline \multirow{2}{*}{$\begin{array}{l}\text { TAXA } \\
\text { Class }\end{array}$} & \multirow[b]{2}{*}{ Family/Genus-Species } & \multicolumn{2}{|c|}{ OCCURRENCE } \\
\hline & & Sample & Dist. group \\
\hline \multirow[t]{4}{*}{ Demospongiae } & Dendrilla antarctica & 1 & 1 \\
\hline & Sphaerotylus antarcticus & 1 & 1 \\
\hline & Mycale acerata & 1,2 & 1,2 \\
\hline & Bubaris antarctica & 2 & 1 \\
\hline \multirow[t]{4}{*}{ Anthozoa } & Edwarsia sp. & 1 & 1,2 \\
\hline & Isotaelia antarctica & 1 & 1,2 \\
\hline & Hormathia sp. & 1 & 1 \\
\hline & Indet Actiniidae (burrowing) & 2 & $1,2,3$ \\
\hline Hydrozoa & Indet. hydroids (bush form) & 1,2 & 1 \\
\hline \multirow[t]{2}{*}{ Anopla } & Parborlasia corrugatus & 1 & 1,2 \\
\hline & Antarctonemertes validum & 1,2 & $1,2,3$ \\
\hline Priapulidea & Priapulus tuberculatospinosus & 2 & 1,2 \\
\hline Sipunculidea & Golfingia sp. & 2 & 1 \\
\hline Turbellaria & Indet. Turbellarian & 2 & 1,2 \\
\hline Adenophorea & Indet. nematodes & 2 & 1,2 \\
\hline \multirow[t]{22}{*}{ Polychaeta } & Barrukia cristata & 1,2 & $1,2,3$ \\
\hline & Aglaophamus antarctica & 2 & $1,2,3$ \\
\hline & Lumbrineris cingulata & 2 & 1,2 \\
\hline & Steggoa magalhaensis & 2 & $1,2,3$ \\
\hline & Nematonereis sp. & 2 & 1,2 \\
\hline & Capitella sp. & 2 & $1,2,3$ \\
\hline & Ophryotrocha sp. & 2 & $1,2,3$ \\
\hline & Rhodine intermedia & 2 & 1 \\
\hline & Ophelina breviata & 2 & $1,2,3$ \\
\hline & Apistobranchus gudrunae & 2 & $1,2,3$ \\
\hline & Myrianida cf. proceraeae & 2 & 1,2 \\
\hline & Autolytus charcoti & 2 & 1,2 \\
\hline & Spiophanes tcherniai & 2 & 1 \\
\hline & Thelepus cincinnatus & 1,2 & 1,2 \\
\hline & Pyllodoce patagonica & 2 & 1 \\
\hline & Aphelochaeta sp & 2 & $1,2,3$ \\
\hline & Kefersteinia fauveli & 2 & 1,2 \\
\hline & Typosyllis armillaris & 2 & 1,2 \\
\hline & Neanthes kerguelensis & 2 & 1,2 \\
\hline & Flabelligera mundata & 1 & 1,2 \\
\hline & Indet. Spirorbidae & 3 & $1,2,3$ \\
\hline & Indet. Serpulidae & 3 & 1,2 \\
\hline \multirow[t]{14}{*}{ Gastropoda } & Nacella concinna & 1,2 & $1,2,3$ \\
\hline & Margarella antarctica & 1,2 & $1,2,3$ \\
\hline & Iothia coppingeri & 1,2 & 1,2 \\
\hline & Eatoniella calignosa & 2 & $1,2,3$ \\
\hline & Onoba turqueti & 2 & $1,2,3$ \\
\hline & Onoba gelida & 2 & $1,2,3$ \\
\hline & Onoba kergueleni & 2 & 1 \\
\hline & Toledonia limnaeformis & 2 & 1,2 \\
\hline & Toledonia punctata & 2 & 1,2 \\
\hline & Laevilitorina antarctica & 2 & $1,2,3$ \\
\hline & Marseniopsis mollis & 1 & 1 \\
\hline & Tritionella belli & 1 & 1 \\
\hline & Notaeolidia depressa & 1,2 & $1,2,3$ \\
\hline & Austrodoris kerguelensis & 1 & 1 \\
\hline Polyplacophora & Callochiton steinii & 2 & 1,2 \\
\hline \multirow[t]{3}{*}{ Bivalva } & Adacnarca nitens & 2 & 1,2 \\
\hline & Mysella charcoti & 2 & $1,2,3$ \\
\hline & Yoldia eightsi & 1,2 & 1 \\
\hline
\end{tabular}


Appendix 1 (continued)

\begin{tabular}{|c|c|c|c|}
\hline \multirow{2}{*}{$\begin{array}{l}\text { TAXA } \\
\text { Class }\end{array}$} & \multirow[b]{2}{*}{ Family/Genus-Species } & \multicolumn{2}{|c|}{ OCCURRENCE } \\
\hline & & Sample & Dist. group \\
\hline \multirow{36}{*}{ Malacostraca } & Cyamiomactra laminifera & 2 & 1,2 \\
\hline & Thyasira bongraini & 2 & 1 \\
\hline & Laternula elliptica & 1,2 & $1,2,3$ \\
\hline & Philobrya sublaeris & 2 & 1,2 \\
\hline & Philobrya wandelensis & 2 & 1,2 \\
\hline & Campylaspis maculata & 2 & $1,2,3$ \\
\hline & Vaunthompsonia inermis & 2 & 1,2 \\
\hline & Eudorella fallax & 2 & $1,2,3$ \\
\hline & Caecognathia antarctica & 2 & 1,2 \\
\hline & Harrietonana cf subtriangulata & 2 & $1,2,3$ \\
\hline & Cymodoce antarctica & 2 & $1,2,3$ \\
\hline & Austrosignum glaciale & 2 & $1,2,3$ \\
\hline & Austofilius serratus & 2 & 1,2 \\
\hline & Munna sp. & 2 & 1,2 \\
\hline & Paraceradocus gibber & 2 & 1,2 \\
\hline & Schraderia gracilis & 2 & $1,2,3$ \\
\hline & Methalimedon nordenskjoeldi & 2 & $1,2,3$ \\
\hline & Oradarea rossi & 2 & 1,2 \\
\hline & Oradarea tridentate & 2 & 1,2 \\
\hline & Oradarea edentata & 2 & $1,2,3$ \\
\hline & Thaumatelson herdmani & 2 & $1,2,3$ \\
\hline & Pachychelium nichollsi & 2 & 1,2 \\
\hline & Antatelson walkeri & 2 & 1,2 \\
\hline & Indet. Phoxocephalidae & 2 & 1,2 \\
\hline & Cheirimedon femoratus & 2 & $1,2,3$ \\
\hline & Prostebbingia brevicornis & 2 & $1,2,3$ \\
\hline & Prostebbingia longicornis & 2 & $1,2,3$ \\
\hline & Indet. Calliopiidae & 2 & 1,2 \\
\hline & Monoculodes cf scabriculosus & 2 & $1,2,3$ \\
\hline & Indet. Oedicerotidae & 2 & $1,2,3$ \\
\hline & Gondogeneia antarctica & 2 & 2 \\
\hline & Nototanais dimorphus & 2 & $1,2,3$ \\
\hline & Indet. Philomedidae & 2 & $1,2,3$ \\
\hline & Hemicythere sp. & 2 & $1,2,3$ \\
\hline & Philomedes sp. b & 2 & $1,2,3$ \\
\hline & Scleroconcha sp. & 2 & $1,2,3$ \\
\hline \multirow[t]{4}{*}{ Pycnogona } & Pentanymphon antarcticum & 2 & 1 \\
\hline & Austrodecus sp. & 2 & 1,2 \\
\hline & Nymphon sp. & 2 & 1 \\
\hline & Austropallene sp. & 2 & 1 \\
\hline Echinoidea & Sterechinus neumayeri & 1,2 & $1,2,3$ \\
\hline Ophiuroidea & Ophionotus victoriae & 1,2 & $1,2,3$ \\
\hline \multirow[t]{5}{*}{ Asteroidea } & Odontaster validus & 1,2 & $1,2,3$ \\
\hline & Cryptasterias turqueti & 1,2 & 1,2 \\
\hline & Diplasterias brucei & 1,2 & 1,2 \\
\hline & Perknaster aurorae & 1 & 1 \\
\hline & Porania antarctica & 1 & 1 \\
\hline \multirow[t]{3}{*}{ Holothuroidea } & Heterocucumis steineni & 1,2 & 1,2 \\
\hline & Cucumaria sp & 1,2 & 1,2 \\
\hline & Echinopsis acanthocola & 1,2 & 1 \\
\hline Crinoidea & Promachocrinus kerguelenses & 1 & 1 \\
\hline \multirow[t]{4}{*}{ Ascidacea } & Cnemidocarpa verrucosa & 1,2 & 1,2 \\
\hline & Pyura discoveri & 1 & 1 \\
\hline & Sycozoa sigillinoides & 2 & 1 \\
\hline & Indet. Dideminidae & 1 & 1 \\
\hline \multirow[t]{2}{*}{ Stenolaemata } & Tubulipora sp. & 3 & $1,2,3$ \\
\hline & Discoporella sp. & 3 & 1 \\
\hline
\end{tabular}


Appendix 1 (continued)

\begin{tabular}{|c|c|c|c|}
\hline \multirow{2}{*}{$\begin{array}{l}\text { TAXA } \\
\text { Class }\end{array}$} & \multirow[b]{2}{*}{ Family/Genus-Species } & \multicolumn{2}{|c|}{ OCCURRENCE } \\
\hline & & Sample & Dist. group \\
\hline \multirow[t]{13}{*}{ Gymnolaemata } & Kymella polaris & 1 & 1 \\
\hline & Aimulosia antarctica & 3 & 1 \\
\hline & Arachnopusia inchoate & 3 & $1,2,3$ \\
\hline & Beania erecta & 3 & 1 \\
\hline & Cellaporella antarctica & 3 & $1,2,3$ \\
\hline & Cellaporella bougainvillea & 3 & $1,2,3$ \\
\hline & Ellisina antarctica & 3 & 1,2 \\
\hline & Fenestrulina rugula & 3 & $1,2,3$ \\
\hline & Hippadanella inerma & 3 & $1,2,3$ \\
\hline & Micropora notialis & 3 & 1,2 \\
\hline & Smittina rogickae & 3 & 1,2 \\
\hline & Valdemunitella lata & 3 & 1 \\
\hline & Xylochotridens rangifer & 3 & $1,2,3$ \\
\hline
\end{tabular}

Editorial responsibility: Otto Kinne (Editor-in-Chief), Oldendorf/Luhe, Germany
Submitted: May 10, 2007; Accepted: June 15, 2007

Proofs received from author(s): October 15, 2007 